\title{
Cadmium toxicity affects chlorophyll $a$ and $b$ content, antioxidant enzyme activities and mineral nutrient accumulation in strawberry
}

\author{
Ferhad Muradoglu', Muttalip Gundogdu', Sezai Ercisli ${ }^{1}$, Tarik Encu ${ }^{3}$, Fikri Balta ${ }^{4}$, Hawa ZE Jaafar ${ }^{5^{*}}$
} and Muhammad Zia-Ul-Haq ${ }^{6^{*}}$

\begin{abstract}
Background: Cadmium (Cd) is well known as one of the most toxic metals affecting the environment and can severely restrict plant growth and development. In this study, Cd toxicities were studied in strawberry cv. Camarosa using pot experiment. Chlorophyll and malondialdehyde (MDA) contents, catalase (CAT), superoxide dismutase $(\mathrm{SOD})$, ascorbate peroxidase (APX) activities and mineral nutrient concentrations were investigated in both roots and leaves of strawberry plant after exposure $\mathrm{Cd}$.

Results: $\mathrm{Cd}$ content in both roots and leaves was increased with the application of increasing concentrations of $\mathrm{Cd}$. We found higher $\mathrm{Cd}$ concentration in roots rather than in leaves. Chlorophyll a and b was decreased in leaves but MDA significantly increased under increased $\mathrm{Cd}$ concentration treatments in both roots and leaves. SOD and CAT activities was also increased with the increase $\mathrm{Cd}$ concentrations. $\mathrm{K}, \mathrm{Mn}$ and $\mathrm{Mg}$ concentrations were found higher in leaves than roots under $\mathrm{Cd}$ stress. In general, increased $\mathrm{Cd}$ treatments increased $\mathrm{K}, \mathrm{Mg}, \mathrm{Fe}, \mathrm{Ca}$, $\mathrm{Cu}$ and $\mathrm{Zn}$ concentration in both roots and leaves. Excessive $\mathrm{Cd}$ treatments reduced chlorophyll contents, increased antioxidant enzyme activities and changes in plant nutrition concentrations in both roots and leaves.

Conclusion: The results presented in this work suggested that $\mathrm{Cd}$ treatments have negative effect on chlorophyll content and nearly decreased $30 \%$ of plant growth in strawberry. Strawberry roots accumulated higher $\mathrm{Cd}$ than leaves. We found that MDA and antioxidant enzyme (CAT, SOD and APX) contents may have considered a good indicator in determining $\mathrm{Cd}$ tolerance in strawberry plant.
\end{abstract}

Keywords: Antioxidant enzymes, Cadmium, Chlorophyll, Heavy metal stress, Strawberry

\section{Background}

Cadmium is believed as one of the most important contaminant in the ecosphere. The main sources of $\mathrm{Cd}$ in environment are mining and smelting of Cd-containing ores, municipal wastes, pesticides, trace emissions, burning of fossil fuels and fertilizers $[1,2]$. In plants, the first organ to contact the toxic metal ions are roots, and therefore roots have greater contents of metal than aerial parts [2]. As compared to other metals like $\mathrm{Zn}, \mathrm{Cu}$ or $\mathrm{Mn}, \mathrm{Cd}$ is a non-essential heavy metal that is non-toxic at low concentrations, but it is toxic at higher

\footnotetext{
*Correspondence: hawazej@gmail.com; ahirzia@gmail.com

${ }^{5}$ Department of Crop Science, Faculty of Agriculture, University Putra

Malaysia, 43400 Selangor, Malaysia

${ }^{6}$ The Patent Office, Karachi, Pakistan

Full list of author information is available at the end of the article
}

concentrations [2]. It manifests its toxicity by inhibiting some growth, changing the plant nutrient contents and composition, and by antagonizing the effects on essential elements and several enzymes activities [3,4]. It induces complex changes in plants at genetic, physiological and biochemical levels, leading to phytotoxicity, whose main indications are leaf rolls, chlorosis and reduction of root and stem growth [5,6], limiting transport of metals [7], respiratory and photosynthetic activities, enzyme activities, hormone balance and membrane functions [8], induction of lipid peroxidation and chlorophyll breakdown in plants [9] and generation of oxidative stress [2,10]. 
Among all side effects induced by $\mathrm{Cd}$, lipid peroxidation is the most harmful as it can lead to bio membrane deterioration. The main indicator of oxidative stress in plants is MDA, which is the decomposition product of polyunsaturated fatty acids of bio membrane [11]. Plants manage the oxidative stress by antioxidant enzymes like CAT, SOD, GPX, APX, GR, and non-enzymatic constituents such as ascorbate and glutathione [12-14]. Among enzymes, SOD is the first line of defense as it converts superoxide radical to hydrogen peroxide $\left(\mathrm{H}_{2} \mathrm{O}_{2}\right)$, which is later reduced to water and oxygen either by APX in ascorbate-glutathione cycle or by GPX and CAT in cytoplasm and other cellular compartments [12]. It is well known that the response of plants to Cd-induced depend on several factors such as genotype, root system, growing condition, agronomic practices employed, climatological and geological conditions of soil, and growing season as well as maturity of plants. Root uptake, root-to-shoot translocation and partitioning of $\mathrm{Cd}$ between plant organs can vary in both plant species and cultivar belongs to single specie [15].

Strawberry (Fragaria $x$ ananassa Duch) has been widely grown worldwide because of adapting to various climate and soil condition. Camarosa cultivar dominates strawberry production in Turkey due to its bigger fruits, high fruit quality and excellent transportation capacity $[16,17]$. Threats of environmental pollution with heavy metals render stress a general concern for the agricultural crops. Strawberry plants exposed to Cd toxicity may experience severe cellular injury that may lead to cell death within a short period. $\mathrm{Cd}$ is easily taken up by strawberry plants and accumulated in organs [18]. Previous studies commonly concerned with the influences of $\mathrm{Cd}$ on the upper part of plants. Little is known of $\mathrm{Cd}$ toxicity to the root system in strawberry plant. This study was an attempt to understand the effect of $\mathrm{Cd}$ treatments on plant growth, antioxidant enzyme activities and mineral nutrients accumulations in both roots and leaves of Camarosa strawberry cultivar.

\section{Results and discussion}

\section{Effect of Cd on chlorophyll and Cd accumulation in strawberry}

As shown in Figure 1. The chlorophyll content in strawberry plant organs decreased under $\mathrm{Cd}$ treatment. There was regularly a reduction attributable to $\mathrm{Cd}$ application both chlorophyll a and chlorophyll b in Camarosa (strawberry) cultivar. Chlorophyll a content was found higher than chlorophyll b content. There was nearly 5 , 15,25 , and $30 \%$ decrease in chlorophyll a and 3, 11, 15 and $18 \%$ decrease in chlorophyll b when Cd applications were increased from 0 to $60 \mathrm{mg} \mathrm{kg}{ }^{-1}$ respectively. According to Qian et al. [19], cadmium-induced declining effect on chlorophyll and carotenoid contents which could be explained on the basis of inhibitory effect of $\mathrm{Cd}$ on enzymes involved in pigment biosynthesis. Furthermore, chlorophyll a and chlorophyll b contents showed significant decline at the applications of $\mathrm{Cd}$ and the results were in consist with earlier report where Cd inhibited the biosynthesis of chlorophyll and generated a kind of senescence $[19,20]$. Our results are in agreement with finding by Yang et al. [21] who reported that leaves of Potamogeton crispus under $\mathrm{Cd}$ stress showed decreased $35,8 \%$ chlorophyll a and $26.7 \%$ chlorophyll b and chlorophyll a content was found higher than chlorophyll b content. Several report have shown that under Cd stress decrease chlorophyll content in leaf garden grass [22] and almond seedling [23]. Therefore, chlorophyll pigments seem to be one of the main reasons of heavymetal injury in plants.

Statistically significant differences among Cd applications for accumulation of $\mathrm{Cd}$ in root and leaf of strawberry plants were observed (Figure 2). Increasing $\mathrm{Cd}$ concentrations were ensuring significant increase $\mathrm{Cd}$ accumulation in both root and leaf. The average $\mathrm{Cd}$ concentration in root was approximately four times higher than in leaf. The $\mathrm{Cd}$ concentration ranged from 0.74 to $3.77 \mathrm{mg} \mathrm{kg}^{-1}$ in root and from 0.27 to $0.79 \mathrm{mg} \mathrm{kg}^{-1}$ in leaf. Increasing $\mathrm{Cd}$ concentrations were increased
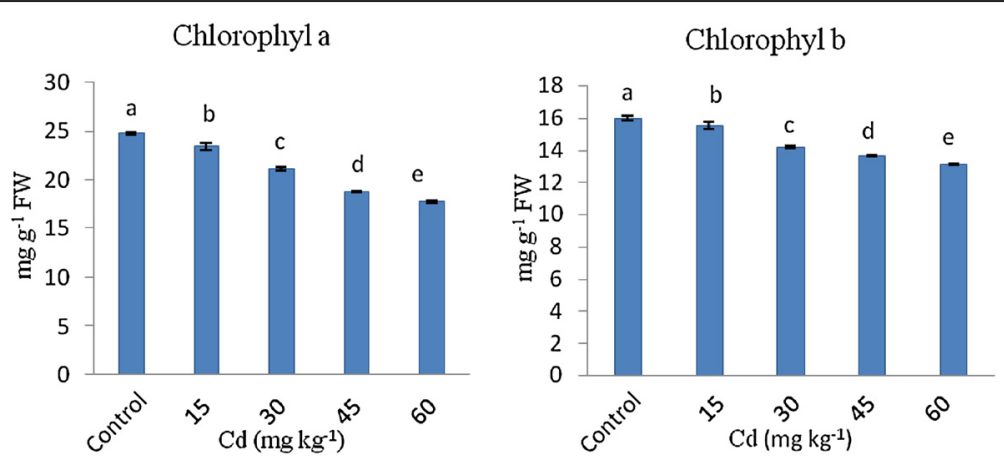

Figure 1 Changes of chlorophyll a and $\mathbf{b}$ contents exposed to different $\mathrm{Cd}$ applications in leaves of strawberry plants. Same letters are not significantly different according to Duncan test ( $p \leq 0.05$ ). 

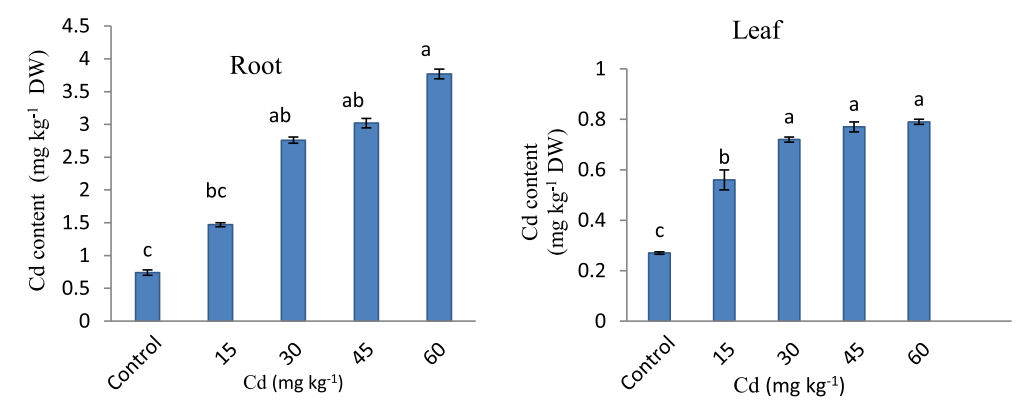

Figure 2 Cadmium accumulation in strawberry plant exposed to different Cd applications. Same letters are not significantly different according to Duncan test ( $\mathrm{p} \leq 0.05)$.

accumulation of $\mathrm{Cd}$ approximately 1.98, 3.72, 4.08 and 5.09 times in root and 2.07, 2.26, 2.85 and 2.92 times in leaf as compared with control respectively. Cd uptake and accumulation in plant differences greatly among species and also among different organs and tissues. $\mathrm{Cd}$ is usually accumulated in the roots, because this is the first organ exposed to heavy metal and it is also translocated into the shoots. Our results showed that the accumulation of $\mathrm{Cd}$ in root was higher than in leaf of strawberry (Figure 2). Similarly, Gill et al. [22] reported that $\mathrm{Cd}$ accumulation in root and leaves increased with the increasing $\mathrm{Cd}$ concentration in soil and $\mathrm{Cd}$ content in root was found higher than leaves in Lepidium sativum. Nada et al. [23] observed similar situation in almond seedling.

\section{Effects of Cd on MDA content}

The increased contents of lipid peroxides are indication of more production of toxic oxygen species than normal. Strawberry plant showed significant increase in MDA production when treated with $\mathrm{Cd}$ applications. Leaf had higher MDA content than root. In root and leaf of strawberry plant, MDA production was increased nearly $30 \%$ in root and 33\%in leaf compare with control after expose to $60 \mathrm{mg} \mathrm{kg}^{-1} \mathrm{Cd}$ application (Figure 3). When plants grow in stressed environments, free-radicals generated in excess, accumulate in the cells. It leads to lipid peroxidation of biomembranes, and its end product is MDA. Therefore, the MDA-concentration is an indicator of physiological stresses and the aging process [8]. Our results showed increase in MDA content in both root and leaf depend on Cd concentrations. Nada et al. [23] observed an increase MDA content in both root and leaf of almond seedlings that exposed to $\mathrm{Cd}$ treatment. This result is in agreement with our study.

\section{Effect of Cd on antioxidant enzyme activity}

The changes in SOD activity were determined in both root and leaf of strawberry with increase in level of $\mathrm{Cd}$ concentrations when compared with control (Figure 4). With increase in Cd concentration in strawberry plant, a steadily increase in SOD was determined in both root and leaf. In every $\mathrm{Cd}$ concentration increase, SOD activity was higher than control. In root, $\mathrm{Cd}$ concentrations caused an increase in SOD activity by 8, 17, 27 and 29\% respectively and in leaf 4, 7, 29 and $34 \%$ as compared with control.

As shown in Figure 5, significant increases were observed in CAT activity. Increasing $\mathrm{Cd}$ concentrations provide to regularly increase CAT activity in root but $\mathrm{Cd}$ concentrations provide a severe increasing in leaf. When the increasing CAT activity was compared with to Control, increasing $\mathrm{Cd}$ concentrations caused an increase in CAT activity by 1.0, 1.2, 1.7 and 2.0 times in root
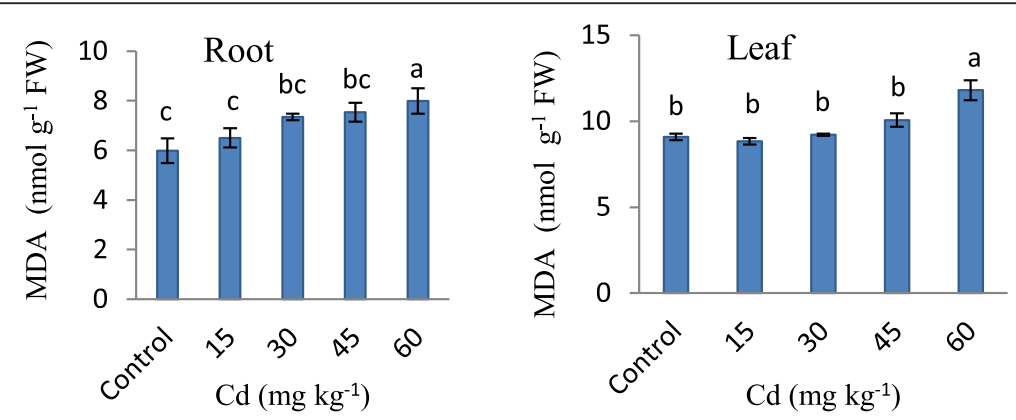

Figure $\mathbf{3}$ Changes in malondialdehyde content in strawberry plant exposed to different $\mathrm{Cd}$ applications. Same letters are not significantly different according to Duncan test ( $p \leq 0.05$ ). 

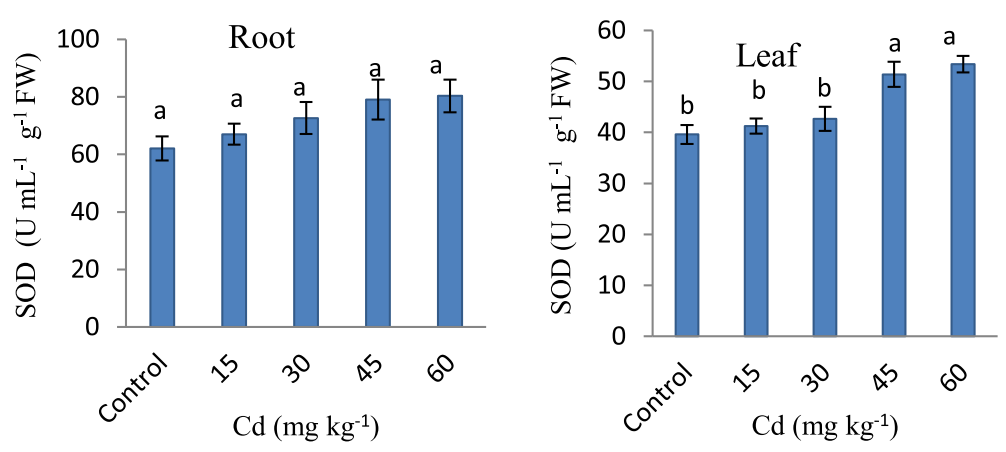

Figure 4 SOD activity in strawberry plant exposed to different $\mathbf{C d}$ applications. Same letters are not significantly different according to Duncan test $(p \leq 0.05)$.

respectively but this increase was followed very sharp by 3, 4, 9 and 19 times in leaves.

APX results are shown in Figure 6. Increasing in APX activity belongs to $\mathrm{Cd}$ concentrations was found statistically significant. APX activity was monitored regularly increased by $124 \%$ in root and $237 \%$ in leaf up to $45 \mathrm{mg}$ $\mathrm{kg}^{-1} \mathrm{Cd}$ concentration as compared control. On the other hand, a decline in APX activity was monitored after $45 \mathrm{mg} \mathrm{kg}^{-1} \mathrm{Cd}$ concentration that this decline was higher than the control by $28 \%$ in root and $74 \%$ in leaf. APX activity in leaf was higher than in root.

The abiotic stresses like heavy metals lead to molecular damage to plant cells by generating reactive oxygen species (ROS) [10]. Although Cd does not generate ROS directly, it generates oxidative stress by interrupting the antioxidant defense system [24]. Produced these ROS mainly include GPX, APX and CAT. These antioxidant enzymes balance the ROS production and destruction. $\mathrm{Cd}$ also inhibits Calvin cycle enzymes and hence accumulated reduced coenzymes will not be able to accept electrons from PSI. In our experiment the activities of catalase, ascorbate peroxidase and superoxide dismutase were measured. Our results showed that 15, 30, 45 and $60 \mathrm{mg} \mathrm{kg}{ }^{-1} \mathrm{Cd}$ concentrations led to a significant increase in the antioxidant enzyme activity (SOD; CAT; APX) in both root and leaf of strawberry (Figures 4, 5 and 6). Our results are in agreement with previous studies that have observed findings of Gill et al. [22] who reported that activities of SOD, CAT and APX were found increased in the leaves of garden gress plant with increased dose of $\mathrm{Cd}$ treatment.

\section{Effect of Cd on mineral concentration of strawberry}

Increasing of $\mathrm{Cd}$ concentrations affected content of mineral elements in Camarosa cultivar. In leaves, $\mathrm{K}, \mathrm{Mg}$ and $\mathrm{Mn}$ content was found higher than in root, but $\mathrm{Fe}, \mathrm{Cu}$ and $\mathrm{Zn}$ content was found higher in root with increasing Cd concentrations (Table 1). In leaves, contents of essential elements ( $\mathrm{Ca}, \mathrm{Mg}, \mathrm{Fe}, \mathrm{Mn}, \mathrm{Cu}$ and $\mathrm{Zn}$ ) were found statistically significant according to $\mathrm{Cd}$ concentrations except $\mathrm{K}$ while $\mathrm{Mg}, \mathrm{Fe}, \mathrm{Mn}$ and $\mathrm{Zn}$ was found statistically significant in root based on $\mathrm{Cd}$ concentrations. Initially $\mathrm{K}, \mathrm{Ca}, \mathrm{Mg} \mathrm{Fe}$ and $\mathrm{Mn}$ contents were tending to increase when compare with control then a slight decrease was observed in both root and leaf at $60 \mathrm{mg} \mathrm{kg}^{-1} \mathrm{Cd}$ concentration. With increasing $\mathrm{Cd}$ concentration $\mathrm{Zn}, \mathrm{Cu}$ and Mn content was observed decrease in both root and leaf except $\mathrm{Cu}$ in root. Nada et al. [23] found that in leaf and root of almond, $\mathrm{Cd}$ addition reduced the concentration of macronutrients such as $\mathrm{Ca}, \mathrm{Mg}$ and $\mathrm{K}$ in leaves and in root. Liu et al. [4] report that the interactions of $\mathrm{Cd}$ and $\mathrm{Fe}, \mathrm{Cu}$ and $\mathrm{Zn}$ are synergetic in uptake and translocation from root to shoot by rice plants. Yang et al. [21] also
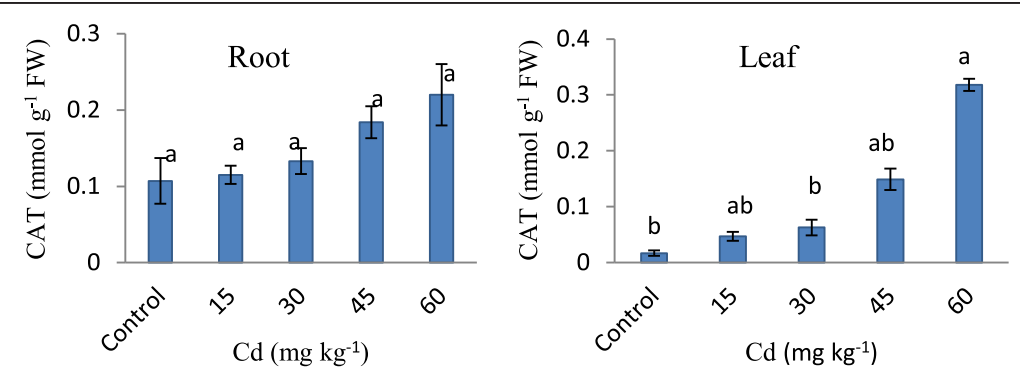

Figure $\mathbf{5}$ CAT activity in strawberry plant exposed to different $\mathbf{C d}$ applications. Same letters are not significantly different according to Duncan test ( $p \leq 0.05)$. 

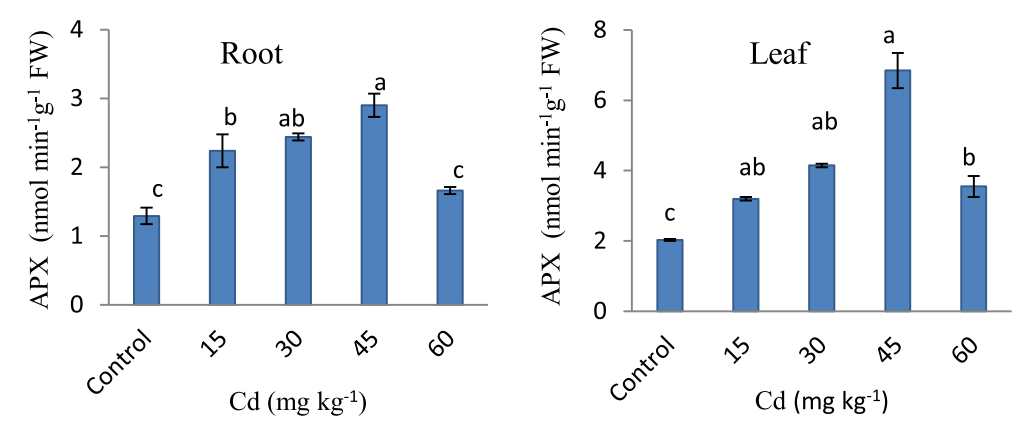

Figure 6 APX activity in strawberry plant exposed to different $\mathbf{C d}$ applications. Same letters are not significantly different according to Duncan test $(p \leq 0.05)$.

reported that a decrease macronutrient ( $\mathrm{K}$ and $\mathrm{P}$ ) contents in Potamogeten crispus.

\section{Conclusions}

The results suggested that increasing $\mathrm{Cd}$ concentrations had negative effect on chlorophyll content and nearly decrease $30 \%$ in leaves. The roots accumulate about higher $70 \% \mathrm{Cd}$ than leaves of strawberry. Results indicated that MDA and antioxidant enzymes (SOD, CAT

Table 1 Effect of Cd applications on macro-micro nutrient elements concentrations of root and leaf of strawberries Camarosa cultivars ( $\mathrm{mg} \mathrm{kg}^{-1} \mathrm{DW}$ )

\begin{tabular}{|c|c|c|c|c|c|c|}
\hline \multicolumn{2}{|c|}{ Cd applications } & \multirow{2}{*}{$\frac{\text { Control }}{3291^{a}}$} & \multirow{2}{*}{$\frac{15}{3608^{a}}$} & \multirow{2}{*}{$\frac{30}{4698^{a}}$} & \multirow{2}{*}{$\frac{45}{4679^{a}}$} & \multirow{2}{*}{$\frac{60}{3784^{a}}$} \\
\hline & Root & & & & & \\
\hline \multirow[t]{3}{*}{ K } & Leaf & $18655^{a}$ & $15325^{a}$ & $16339^{a}$ & $18846^{a}$ & $14921^{a}$ \\
\hline & Root/Leaf & 0.17 & 0.23 & 0.28 & 0.24 & 0.25 \\
\hline & Root & $17144^{a}$ & $17972^{a}$ & $18769^{a}$ & $16295^{a}$ & $15695^{a}$ \\
\hline \multirow[t]{3}{*}{$\mathrm{Ca}$} & Leaf & $11842^{c}$ & $15489^{c}$ & $21105^{a b}$ & $22714^{a}$ & $16302^{b c}$ \\
\hline & Root/Leaf & 1.45 & 1.16 & 0.89 & 0.72 & 0.96 \\
\hline & Root & $4038^{a}$ & $4134^{a}$ & $4215^{a}$ & $3257^{b}$ & $2930^{b}$ \\
\hline \multirow[t]{3}{*}{$\mathrm{Mg}$} & Leaf & $4779^{b}$ & $6037^{a b}$ & $6759^{a b}$ & $7704^{a}$ & $6646^{a b}$ \\
\hline & Root/Leaf & 0.85 & 0.68 & 0.62 & 0.42 & 0.44 \\
\hline & Root & $980^{b}$ & $1333^{a b}$ & $1653^{a}$ & $1439^{a b}$ & $1326^{a b}$ \\
\hline \multirow[t]{3}{*}{$\mathrm{Fe}$} & Leaf & $203^{b}$ & $191^{b}$ & $251^{a}$ & $190^{b}$ & $184^{b}$ \\
\hline & Root/Leaf & 4.82 & 6.96 & 6.59 & 7.58 & 7.19 \\
\hline & Root & $38^{c}$ & $38^{c}$ & $60^{b}$ & $81^{a}$ & $31^{c}$ \\
\hline \multirow[t]{3}{*}{$\mathrm{Mn}$} & Leaf & $105^{d}$ & $148^{c}$ & $202^{b}$ & $230^{a b}$ & $261^{a}$ \\
\hline & Root/Leaf & 0.37 & 0.26 & 0.30 & 0.35 & 0.12 \\
\hline & Root & $15.49^{a}$ & $16.38^{a}$ & $17.10^{a}$ & $18.04^{a}$ & $20.65^{a}$ \\
\hline \multirow[t]{3}{*}{$\mathrm{Cu}$} & Leaf & $10.99^{a b}$ & $8.63^{b c}$ & $8.60^{b c}$ & $13.39^{a}$ & $6.45^{c}$ \\
\hline & Root/Leaf & 1.41 & 1.9 & 1.99 & 1.35 & 3.2 \\
\hline & Root & $206^{a}$ & $52.87^{c}$ & $72.94^{b}$ & $40.30^{d}$ & $35.63^{d}$ \\
\hline \multirow[t]{2}{*}{$\mathrm{Zn}$} & Leaf & $22^{a}$ & $17.69^{b}$ & $17.49^{b}$ & $19.32^{a b}$ & $18.90^{\mathrm{ab}}$ \\
\hline & Root/Leaf & 9.34 & 2.98 & 4.17 & 2.08 & 1.88 \\
\hline
\end{tabular}

Same letters in the same line are not significantly different according to Duncan test $(p \leq 0.05)$. and APX) content are considered to be indicator in determining Cd tolerance in plant. Strawberry plants affected with increased $\mathrm{Cd}$ concentrations. Lipid peroxidation content and antioxidant enzyme activities increased with $\mathrm{Cd}$ concentrations.

\section{Methods}

\section{Plant materials and pot experiment}

The experiment was carried out in the greenhouse of Yuzuncu Yil University during growing period (from middle May to end of July). The experiment was conducted by using frigo plants of Strawberry (Fragaria $x$ ananassa cv. Camarosa) in pot experiment. Four frigo plants were planted into every pot $(72 \times 20 \times 17 \mathrm{~cm})$ that was filled with peat $(4 \mathrm{~kg})$ [25]. Initial stages of grown, plants were fed by adding nutrient solution to the pots. The nutrition solutions contained N 200, Mg 49, K 208, P 37, Ca 167, Mn 1.16, Fe 1.53, Zn 0.09, B 0.46, Cu 0.03 and Mo $0.02 \mathrm{mg} / \mathrm{l}$. Flower buds were cut of early stage of plant's growth. After the plants had four or five leaves about 4 weeks, cadmium applications were started. Cadmium was added to pots at concentration of $0,15,30$, 45 and $60 \mathrm{mg} \mathrm{kg}^{-1}$ in the form of $\mathrm{CdSO}_{4} * 8 \mathrm{H}_{2} \mathrm{O}$ four equal times with watering during growth period. In harvest, 12 plants were harvested to every application, plants were sectioned into roots and leaves and this section was stored at $-80^{\circ} \mathrm{C}$ until antioxidant analyze. Also for macro-micro analysis, fresh root and leafs dried in an oven $\left(80^{\circ} \mathrm{C}\right)$ and dried parts were ground and stored until analyze.

\section{Chlorophyll determination}

Chlorophyll a and chlorophyll b, $0.5 \mathrm{~g}$ fresh leaves were extracted in $80 \%$ acetone and were determined spectrophotometrically by Lichtentaler formula [26].

\section{Lipid peroxidation content}

MDA content, a product of lipid peroxidation, was used to gauge the level of lipid peroxidation [27]. A leaf sample $(0.5 \mathrm{~g})$ was homogenized in trichloro acetic acid, 
TCA (10 ml; 0.1\%). The homogenate was centrifuged (15 $000 \mathrm{~g} ; 5 \mathrm{~min})$ and supernatant was collected. To aliquot $(1.0 \mathrm{ml})$ of the supernatant, $4 \mathrm{ml}$ of $0.5 \%$ thiobarbituric acid (TBA) in TCA (20\%) was added. The mixture was heated at $95^{\circ} \mathrm{C}$ for half an hour and then quickly cooled in an ice bath. After centrifugation (10 $000 \mathrm{~g} ; 10 \mathrm{~min})$, the absorbance of the supernatant was recorded at $532 \mathrm{~nm}$. The value for non-specific absorption at $600 \mathrm{~nm}$ was subtracted. The MDA content was calculated by its extinction coefficient of $155 \mathrm{mM}^{-1} \mathrm{~cm}^{-1}$ and expressed as nmol MDA per gram fresh weight.

\section{Preparation of extracts and determination of antioxidant enzymes}

For the analysis of antioxidant enzyme, $1 \mathrm{~g}$ fresh tissue from fourth leaves and the roots was homojenized in $5 \mathrm{ml}$ cold 0.1 M 0.1 M Na-phospat, $0.5 \mathrm{mM} \mathrm{Na-EDTA}$ and 1 $\mathrm{mM}$ ascorbic acid (pH: 7.5). Samples were centrifuged at $18000 \mathrm{~g}$ for $30 \mathrm{~min}$ at a temperature $4^{\circ} \mathrm{C}$. Then Catalase activity immediately was determined and the supernatant was stored at $-20^{\circ} \mathrm{C}$ until determined for SOD.

CAT activity was determined using the modified Aebi [28] method, by measurement of the decrease in absorbance at $240 \mathrm{~nm}$ for $2 \mathrm{~min}$, in a solution containing $\mathrm{H}_{2} \mathrm{O}_{2}$ $(10 \mathrm{mM})$ in phosphate buffer (pH 7.0; $50 \mathrm{mM})$. Enzyme activity was defined as the consumption of $1 \mu \mathrm{mol} \mathrm{H}_{2} \mathrm{O}_{2}$ per min and $\mathrm{mL}$ using a molar absorptivity of $39.4 \mathrm{mM}^{-1}$ $\mathrm{cm}^{-1}$.

SOD activity was measured by monitoring the inhibition of nitroblue tetrazolioum (NBT) reduction at $560 \mathrm{~nm}$ as reported by Giannopolitis and Ries [29]. The reaction mixture contained phosphate buffer $(\mathrm{pH} 7 ; 50 \mathrm{mM})$, NaEDTA $(0.1 \mathrm{mM})$, riboflavin $(75 \mu \mathrm{M})$, methionine $(13 \mathrm{mM})$ and enzyme extract (0.1-0.2 ml). Reaction was carried out in test tubes at $25^{\circ} \mathrm{C}$ under fluorescent lamp (40 W) with irradiance of $75 \mu \mathrm{mol} \mathrm{m} \mathrm{m}^{-2} \mathrm{~s}^{-1}$. The reaction was allowed to run for $10 \mathrm{~min}$ and stopped by switching the light off. Blanks and controls were run similarly but without irradiation and enzyme, respectively. Under the experimental condition, the initial rate of reaction, as measured by the difference in increase of absorbance at $560 \mathrm{~nm}$ in the presence and absence of extract, was proportional to the amount of enzyme.

APX activity was assayed according to the method of Nakano and Asada [30] by recording the decrease in ascorbate content at $290 \mathrm{~nm}$, as ascorbate was oxidized. The reaction mixture contained potassium phosphate buffer (pH 7.0; $50 \mathrm{mM})$, ascorbic acid (5 mM), EDTA $(0.1 \mathrm{mM}), \mathrm{H}_{2} \mathrm{O}_{2}(0.1 \mathrm{~m} \mathrm{M})$ and diluted enzyme $(0.1 \mathrm{ml})$ in a total volume of $3.0 \mathrm{ml}$. The reaction was started with the addition of $\mathrm{H}_{2} \mathrm{O}_{2}$ and absorbance was recorded at $290 \mathrm{~nm}$ spectrophotometrically for $1 \mathrm{~min}$.

\section{Macronutrient and micronutrient determination}

İn dried leaves and roots, $\mathrm{Cd}$ contents and others nutrient element concentrations were analyzed by an atomic absorption spectrophotometer (Varian Techtron Model AAS 1000, Varian Associates, Palo Alto, CA). The samples, which were digested in an acid solution (HCL 3\%) were passed through the AAS system using different lamps, and calibrated with related minerals in different concentrations for different micronutrients.

\section{Statistical analysis}

The experiment was designed as a complete random block design and all measurements were replicated four times. The statistical analysis of the data obtained was performed using the software SPSS 22.0. The results were subjected to one-way ANOVA using the Duncan test to check for significant differences between means $(\mathrm{p}<0.05)$. Error bars in graphs represent \pm standard error.

\section{Competing interests}

The authors declare that they do not have competing interests.

\section{Authors' contributions}

FM, MG, SE and TE made a significant contribution to experiment design, acquisition of data, analysis and drafting of the manuscript. FB, MZ, HZEJ and SE have made a substantial contribution to interpretation of data, drafting and carefully revising the manuscript for intellectual content. All authors read and approved the final manuscript.

\section{Acknowledgements}

This research was supported by Yuzuncu Yil Universty of the head of scientific research (BAP), Van, Turkey, Project No.: 2010-ZF-B015.

\section{Author details}

${ }^{1}$ Department of Horticulture, Faculty of Agriculture and Natural Sciences, Abant Izzet Baysal University, Bolu, Turkey. ${ }^{2}$ Department of Horticulture, Faculty of Agriculture, Ataturk University, Erzurum, Turkey. ${ }^{3}$ Department of Horticulture, Faculty of Agriculture, Yuzuncu Yil University, Van, Turkey. ${ }^{4}$ Department of Horticulture, Faculty of Agriculture, Ordu University, Ordu, Turkey. ${ }^{5}$ Department of Crop Science, Faculty of Agriculture, University Putra Malaysia, 43400 Selangor, Malaysia. ${ }^{6}$ The Patent Office, Karachi, Pakistan.

Received: 5 November 2014 Accepted: 31 January 2015

Published online: 20 February 2015

\section{References}

1. Ozbek K, Cebel N, Unver I. Extractability and phytoavailability of cadmium in Cd-rich pedogenic soils. Turk J Agric For. 2014;38:70-9.

2. Hassan M, Mansoor S. Oxidative stress and antioxidant defense mechanism in mung bean seedlings after lead and cadmium treatments. Turk J Agric For. 2014;38:55-61.

3. Zornoza P, Vazquez S, Esteban E, Fernandez-Pascual M, Carpena R. Cadmium-stress in nodulated white lupin: strategies to avoid toxicity. Plant Physiol Bioc. 2002;40:1003-9.

4. Liu J, Li K, Xu J, Liang J, Lu X, Yang J, et al. Interaction of Cd and five mineral nutrients for uptake and accumulation in different rice cultivars and genotypes. Field Crop Res. 2003:83:271-81

5. Smeets K, Cuypers A, Lambrechts A, Semane B, Hoet P, Laerve AV, et al. Induction of oxidative stress and antioxidative mechanisms in Phaseolus vulgaris after Cd application. J Plant Physiol Biochem. 2005;43:437-44.

6. Mishra S, Srivastava S, Tripathi RD, Govidarajan R, Kuriakose SV, Prasad MNV. Phytochelatin Synthesis and response of antioxidants during cadmium stress in Bacopa monnieri L. J Plant Physiol Biochem. 2006;44:25-37.

7. Barcelo J, Poschenrieder C. Plant water relations as affected by heavy metal stress: a review. J Plant Nutr. 1990;13:1-37. 
8. Chen YX, He YF, Luo YM, Yu YL, Lin Q, Wong MH. Physiological mechanism of plant roots exposed to cadmium. Chemosphere. 2003;50:789-93.

9. Hegedus A, Erdei S, Janda T, Toth E, Horvath G, Dubits D. Transgenic tobacco plants over producing alfafa aldose/aldehyde reductase show higher tolerance to low temperature and Cadmium stress. Plant Sci. 2004;166:1329-33.

10. Zhang H, Jiang $Y$, He Z, Ma M. Cadmium accumulation and oxidative burst in garlic (Allium sativum). J Plant Physiol. 2005;162:977-84.

11. Demiral T, Turkan I. Comparative lipid peroxidation, antioxidant defense systems and proline content in roots of two rice cultivars differing in salt tolerance. Environ Exp Bot. 2005:53:247-57.

12. Asada K. The water-water cycle in chloroplasts: scavenging of active oxygen's and dissipation of excess photons. Annu Rev Plant Physiol Plant Mol Biol. 1999;50:601-39.

13. Shah K, Ritambhara GK, Verma S, Dubey RS. Effect of cadmium on lipid peroxidation, superoxide anion generation and activities of antioxidant enzymes in growing rice seedlings. Plant Sci. 2001;161:1135-44.

14. Sbartai H, Rouabhi R, Sbartai I, Berrebbah H, Djebar RM. Induction of antioxidative enzymes by cadmium stress in tomato (Lycopersicon esculentum). Afr J Plant Sci. 2008;2:72-6.

15. Grant CA, Buckley WT, Bailey LD, Selles F. Cadmium accumulation in crops. Canadian J Plant Sci. 1998;78:1-17.

16. Esitken A, Yildiz HE, Ercisli S, Donmez MF, Turan M, Gunes A. Effects of plant growth promoting bacteria (PGPB) on yield, growth and nutrient contents of organically grown strawberry. Sci Hortic. 2010;124(1):62-6.

17. Torun AA, Aka Kacar Y, Erdem N, Bicen B, Serce S. In vitro screening of octoploid Fragaria chiloensis and Fragaria virginiana genotypes against iron deficiency. Turk J Agric For. 2014;38:169-79.

18. Treder W, Cieslinski G. Cadmium uptake and distribution in strawberry plants as affected by its concentration in soil. J Fruit Ornam Plant Res. 2000;8:127-35

19. Qian H, Li J, Sun L, Chen W, Sheng GD, Liu W, et al. Combined effect of copper and cadmium on Chlorella vulgaris growth and photosynthesisrelated gene transcription. Aquat Toxicol. 2009;94:56-61.

20. Fang Z, Bouwkamp JC, Solomos T. Chlorophyllase activities and chlorophyll degradation during leaf senescence in non-yellowing mutant and wild type of Phaseolus vulgaris L. J Exp Bot. 1998:49:503-10.

21. Yang HY, Shi GX, Xu QS, Wang HX. Cadmium effects on mineral nutrition and stress-related induces in Potamogeton criprus. Russ J Plant Physl. 2011;58:253-60.

22. Gill SS, Khan NA, Tuteja N. Cadmium at high dose perturbs growth, photosynthesis and nitrogen metabolism while at low dose it up regulates sulfur assimilation and antioxidant machinery in garden cress (Lepidium sativum L.). Plant Sci. 2012;182:112-20.

23. Nada E, Ferjani BA, Rhouma A, Bechir BR, Imed M, Makki B. Cadmium-induced growth inhibition and alteration of biochemical parameters in almond seedlings grown in solution culture. Acta Physiol Plant. 2007;29:57-62.

24. di Toppi S, Gabrielli R. Response to cadmium in higher plants. Environ Exp Bot. 1999;41:105-30.

25. Sahin U, Anapali O, Ercisli S. Physico-chemical and physical properties of some substrates used in horticulture. Gartenbauwissenshaft. 2002;67(2):55-60.

26. Lichtentaler HK. Chlorophyll and carotenoids pigments of photosynthetic biomembranes. Meth Enzymol. 1994;148:350-82.

27. Heath RL, Packer L. Photoperoxidation in isolated chloroplast. I. Kinetics and stoichiometry of fatty acid peroxidation. Arch Biochem Biophys. 1968;125:189-98.

28. Aebi H. Catalase in vitro. Methods Enzymol. 1984;105:121-6.

29. Giannopolitis CN, Ries SK. Superoxide dismutase. I. Occurrence in higher plants. Plant Physiol. 1977:59:309-14.

30. Nakano $Y$, Asada K. Hydrogen peroxide is scavenged by ascorbate specific peroxidase in spinach Chloroplasts. Plant Cell Physiol. 1981;22:867-80.

\section{Submit your next manuscript to BioMed Central and take full advantage of:}

- Convenient online submission

- Thorough peer review

- No space constraints or color figure charges

- Immediate publication on acceptance

- Inclusion in PubMed, CAS, Scopus and Google Scholar

- Research which is freely available for redistribution

Submit your manuscript at www.biomedcentral.com/submit 